\title{
Comparative Analysis of Czech Accounting with International Regulation from SMEs Perspective ${ }^{\#}$
}

\author{
Jiř́ STROUHAL ${ }^{*}$ - Marie PASEKOVÁ ${ }^{* *}$ \\ Libuše MÜLLEROVÁ
}

\section{Introduction}

The tightening of professional accounting standards and the proliferation of extensive and complex accounting pronouncements governing financial reporting have added complexities to the preparation of financial statements and have further exacerbated their financial reporting problem. The biggest obstacle is existence of 27 different systems of accounting within the European Union, which have to be harmonized. The question about whether or not accounting standards should apply equally to large and small companies has been the subject of much debate and concern by accountancy bodies in many countries (Maingot and Zeghal, 2006) and has become known as the "Big GAAP/Little GAAP" debate (Collis et al., 2001).

Size is an important determinant for accounting differentiation. The empirical research studies leaving still a considerable gap of ignorance about the influence of an entity's size on the attitudes of its representatives and its stakeholders with regard to financial reporting.

\# This paper is one of the research outputs of the project MSM 6138439903 Development of Financial and Accounting Theory and its Application in Practice from Interdisciplinary Point of View registered at Ministry of Education CR (MŠMT) and project GA402/09/0225 registered at Czech Science Foundation (GAČR).

Ing. Jiří Strouhal, Ph.D. - Senior Lecturer; Department of Financial Accounting and Auditing, Faculty of Finance and Accounting, University of Economics, Prague, W. Churchill Sq. 4, 13067 Prague, Czech Republic; <strouhal@vse.cz>.

** Doc. Ing. Marie Paseková, Ph.D. - Associate Professor; Department of Finance and Accounting, Faculty of Management and Economics, Tomas Bata University in Zlín, T. G. Masaryk Square 5555, 76001 Zlín, Czech Republic; <pasekova@ fame.utb.cz>.

**** Prof. Ing. Libuše Müllerová, CSc. - Professor; Department of Financial Accounting and Auditing, Faculty of Finance and Accounting, University of Economics, Prague, W. Churchill Sq. 4, 13067 Prague 3, Czech Republic; $<$ muller@vse.cz>. 
Some studies have concentrated on the particularities of SMEs with regard to the objectives, purposes and users of financial statements of SMEs. Those are, e.g. (Abdel-Khalik, 1983; Barker and Noonan, 1996; Carsberg et al., 1985; Collis and Jarvis, 2000; Page, 1984; Pratten, 1998). Other studies focused on the attitudes and behavior of SMEs with regard to financial statements' publication and audit (Collis et al., 2004).

However, the arguments for differential reporting seem to be stronger the important argument now appears to be, not whether this is an appropriate approach but rather how accounting standards for large entities and SMEs should differ (Eirle, 2005). It must be decided what criteria will be used for distinguishing different classes of reporting entities and these should reflect cost/benefit considerations (Eirle, 2005).

Specific accounting standards created for a category of enterprises that is so difficult and subjective to define and identify might be ineffective, difficult to interpret and also, difficult to regulate and to maintain (Evans et al., 2005).

One the main arguments for extending IFRS implementation to SMEs' accounts is that global financial reporting standard (if applied consistently) will enhance international comparability and understandability (Pacter, 2004), as well as, the transparency and accountability of SMEs accounting reports (Evans et al., 2005). Greater information relevance, which is also beneficial for management and market efficiency are other suggested benefits for SMEs by the extension of IFRS (Marten et al., 2002).

IASB finalized in 2009 its effort on the wider spread of international accounting standardization issuing brand-new standard IFRS for Small and Medium-Sized Entities (IFRS for SMEs). This standard in fact brought a lot of positive and reasonable simplification of rules from "full IFRS" for the necessities of SME businesses. However it is necessary to state that certain "full IFRS" requirements were not simplified or superseded, but only shortened. This leads to the worse understandability of this standard among SMEs. Due to this reason can be stated that IFRS for SMEs is still not required as a reporting framework within lots of countries or within European Union.

IFRS for SMEs defines "small and medium-sized enterprises" as entities that do not have public accountability, and publish general 
purpose financial statements for external users. Every entity has some form of accountability, if only to its owners and the local tax authorities. Note that size is not the determining factor as to which entitles can use the IFRS for SMEs - the applicability is based entirely on whether the entity has public accountability or not. Therefore, entities that wish to apply the standard may vary in size from very small to substantial private entities. Hence, the standard potentially could have a large audience. The IASB estimates that $95 \%$ of all companies meet these criteria.

There is some evidence that suggests the difficulties or the failure of the adoption process: the lack of political will, rooted in local culture and a strong national outlook prevented a truly harmonized framework, a magnitude of the differences that exist between countries and the high costs to eliminate them (Jermakowicz and Gornik-Tomaszewski, 2006); local traditions exercise a strong influence over the implementations of new concepts (as previously noted on true and fair view) (Sucher and Jindřichovská, 2004); tax and legally-based orientation hinder the harmonization process (Larson and Street, 2004; Vellam, 2004); diversity will not disappear as it comes from different accounting cultures and their interpretation will be partly influenced by their history and previous practice (Alexander and Servalli, 2009; Hoogendoorn, 2006; Schipper, 2005; Soderstrom and Sun, 2007; Strouhal, 2011; Tokar, 2005).

Several questions arise in this context: are transition countries, while their accounting models have understandably less tradition, more at ease to implement full IFRSs and the IFRS for SMEs? Are the differences between local practices and IFRSs more easily to be reduced? Previous studies show that even if some changes towards Substance over Form and a focus on investors have been tempted, the emphasis on compiling proper accounting records and on adhering to tax regulations rather than fairly presenting financial statements has continued in the Czech Republic (Strouhal et al., 2009; Sucher and Jindřichovská, 2004), and considerable differences between the Polish regulations and IFRS were identified given the legalistic and rule-based orientation of Polish rules (Vellam, 2004). Also, problems associated with lack of clarity in the fiscal law, a variable level of understanding of IFRSs by the regulators and preparers, the persistence of the communist mentality among accountants who gained their knowledge and skills prior the transition, the accountants' preference for more prescriptive regulation and less choice of accounting treatments, were also documented (Vellam, 2004). 


\section{Comparative Analysis of Czech Accounting System with International Referential}

\section{Some Brief History}

Until 1918 was Czech lands part of Austrian monarchy and it was applied the Austrian accounting legislature. The requirements on preparation of balance sheet were based on General Austrian Land Code from 1798. General Commercial Code was adopted in 1862 requiring the preparation of balance sheet on yearly basis. It is an interesting fact that this Code was valid even in Czechoslovakia until 1948. In 1964 was adopted new Commercial Code mentioning the requirement that accounting has to follow the long-term state development planning. Seven years later was issued the Act on Unified System of Socioeconomic Information where was mentioned what shall be included within the information system. It was necessary to cover the information from accounting, budgeting, calculation, statistics, and operational evidence (Strouhal et al., 2011).

After the revolution was adopted in 1990 Act on Enterprise requiring from entrepreneurs leading of accounting and providing of information about income, expenditures, accounting profit, assets and liabilities. Entrepreneurs could lead at that time single- or double-entry bookkeeping.

The most important day for Czech accounting was 12.12.1991 when was adopted Accounting Act (593/1991) with validity from 1992. From that time this act was more than 20times amended (Strouhal et al., 2011). The case of the Czech Republic is interesting through the choice made in 1991 referring to building the national accounting system based on the French model, even though the cultural semblance and linguistic closeness criteria did not characterize, during that period, the relationship between France and the Czech Republic (Matis et al., 2009). The arguments for this choice are similar following:

- the intention of creating a certain frontier for the German great economic interest in the Czech economy; even though the German model caught the Czechs' attention;

- English model didn't have enough credibility because of its' dispersion and because of some scandals which were publicly presented;

- American model seemed to be complicated and difficult to implement; and 
- the aim of the Czech Republic to integrate within the E.U. (majority of E.U. countries use the French model).

\section{Current Stage}

Current accounting legislation in the Czech Republic is following:

- general legislation

- Accounting Act (563/1991);

- Decree of Ministry of Finance for entrepreneurs (500/2002);

- Czech Accounting Standards for entrepreneurs;

- other legislation

- Decree of Ministry of Finance for financial institutions (501/2002);

- Czech Accounting Standards for financial institutions;

- Income Tax Act (586/1992);

- Act on Provisions (593/1992);

- Commercial Code (513/1991);

- interpretations of National Accounting Board (not legally binding).

Accounting Act defines as an accounting entity following subjects:

- all legal entities based in the Czech Republic;

- foreign entities carrying their business in the Czech Republic;

- organization unit of state;

- physical entities in case they are registered in the Business Register;

- physical entities with the turnover higher than 25,000,000 CZK;

- other physical entities, voluntarily leading the accounting books instead of simplified tax evidence.

There are applied following measurement bases in Czech accounting:

- $\operatorname{cost}(\mathrm{C})$

- replacement cost (RC);

- own costs (OC);

- nominal value (NV);

- fair value (FV).

Following Tab. 1 summarizes the use of the measurement bases upon initial recognition and upon subsequent measurement: 
Tab. 1: Measurement Bases and Its Use in Czech Accounting Legislature

\begin{tabular}{|l|l|l|}
\hline Balance Sheet Item & $\begin{array}{l}\text { Initial } \\
\text { Recognition }\end{array}$ & $\begin{array}{l}\text { Subsequent } \\
\text { Measurement }\end{array}$ \\
\hline Intangibles & $\mathrm{C}, \mathrm{RC}, \mathrm{OC}$ & $\begin{array}{l}\text { net value, or LCM } \\
\text { model }\end{array}$ \\
\hline Depreciated Tangibles & $\mathrm{C}, \mathrm{RC}, \mathrm{OC}$ & $\begin{array}{l}\text { net value, or LCM } \\
\text { model }\end{array}$ \\
\hline Non-depreciated Tangibles & $\mathrm{C}, \mathrm{RC}, \mathrm{OC}$ & LCM model \\
\hline Shares - controlling influence & $\mathrm{C}$ (RC) & equity method \\
\hline Shares - substantial influence & $\mathrm{C}$ (RC) & equity method \\
\hline Other securities & $\mathrm{C}, \mathrm{RC}$ & FV \\
\hline Purchased inventories & $\mathrm{C}, \mathrm{RC}$ & LCM model \\
\hline Own inventories & $\mathrm{OC}$ & \\
\hline Receivables & $\mathrm{NV}, \mathrm{C}$ & $\begin{array}{l}\text { LCM model or FV } \\
\text { (for derivatives) }\end{array}$ \\
\hline Cash and equivalents & $\mathrm{NV}$ & \\
\hline Securities held for trading & $\mathrm{C}, \mathrm{RC}$ & FV \\
\hline Registered capital & $\mathrm{NV}$ & \\
\hline Issued bonds & $\mathrm{NV}$ & \\
\hline Liabilities & $\mathrm{NV}$ & $\begin{array}{l}\text { NV or FV } \\
\text { (for derivatives) }\end{array}$ \\
\hline
\end{tabular}

Source: Strouhal et al. (2011)

To summarize the current stage of accounting legislature, there shall be stated following "open chapters":

- absolute lack of definition of basic items of financial statements;

- there does not exist any definition of assets, liabilities, equity, expenses or revenues;

- application of "substance-over-form" rule when reporting the financial leases;

- introduction of effective interest rate and amortized costs as a possible measurement base;

- wider spread of fair value approach;

- depends on the liquidity and transparency of markets. 


\section{Differences between Czech Accounting Practices and IFRS for SMEs Requirements}

In general there could be stated, that there is commonly used the historical costs approach rather than fair value accounting (Strouhal et al., 2011; Strouhal and Deari, 2010).

Intangibles - there could be stated that there are any significant differences from the measurement point of view. Like under IFRS for SMEs there are used costs upon initial recognition and costs less accumulated amortization and impairment losses upon balance sheet day. Useful life of intangibles in the Czech Republic is given by the Income Tax Act and there is expected that accounting unit will use the linear method of amortization. However under Czech legislation there are considered as intangibles incorporation expenses and research, which are not recognized as assets under international referential. The requirements on disclosed information are not specified in detail within Czech accounting legislature.

Tangible Assets - there could be stated that there are any significant differences from the measurement point of view for the category known under IFRS for SMEs as "Property, plant and equipment". Like under IFRS for SMEs there are used costs upon initial recognition and costs less accumulated depreciation and impairment losses upon balance sheet day. The requirements on disclosed information are not specified in detail within Czech accounting legislature.

Investment Properties - do not form a special category under Czech accounting regulation. Therefore there are used the very same rules like for any other tangible assets. This leads to the recognition of the difference from IFRS for SMEs, where is applied the fair value approach. The requirements on disclosed information are not specified in detail within Czech accounting legislature.

Leases - there are any significant differences for reporting of operational leases. The treatment of financial leases is totally different when applying Czech and international rules. Under Czech accounting regulation there is not applied "substance-over-form" rule and it is the lessor who recognizes the object of financial lease and depreciates it. Lessee is allowed just to post the rental payments as an expense of the period; however the rental payments have to be on straight-line basis due to the requirements of Income Tax Act. The requirements on 
disclosed information are not specified in detail within Czech accounting legislature.

Inventories - the treatment of inventories fully complies with IFRSs and there could not be seen any significant differences. However, the requirements on disclosed information are not specified in detail within Czech accounting legislature.

Financial Assets - are measured upon initial recognition at cost. Upon balance sheet day there could be applied equity method or fair value approach for shares, and fair value approach for derivatives. Czech accounting however does not apply the amortized costs (or present values) as a measurement base. The division of bonds discounts or premiums shall be therefore straight-line based and the effective interest rate is not applied. The hedge accounting criteria are based on IAS 39 Financial instruments: recognition and measurement. The treatment of fair value hedge and cash flow hedge is very same like under "big set" of IFRS. The requirements on disclosed information are not specified in detail within Czech accounting legislature.

Receivables and Liabilities - are measured at nominal values and it does not matter whether they are long- or short-term based. The amortized costs (or present values) as well as the effective interest rate are not applied. The deferred items are presented separately on balance sheet and not as a part of receivables or liabilities. Long-term receivables are reported as a part of current assets on balance sheet. The requirements on disclosed information are not specified in detail within Czech accounting legislature.

Provisions - are measured at nominal values. The time value of money is not applied upon Czech accounting legislature. The most popular provision in the Czech Republic, i.e. the provision on repair of tangible assets, is strictly prohibited under IFRS for SMEs. The requirements on disclosed information are not specified in detail within Czech accounting legislature.

\section{Research Design}

A significant number of international accounting studies within research literature focus on issues related to formal and material harmonization. Formal harmonization or de jure harmonization studies mainly deal with quantifying the compatibility degree between the international accounting regulations (IFRS) and different national 
accounting regulations (NAS). On the other hand material or de facto harmonization studies mainly analyze, quantify and interpret to what extent the foresights of the international accounting regulations (IFRS) are actually found within entities' accounting practices (Ding et al., 2003; Fontes et al., 2005; Garrido et al., 2002; Larson and Kenny, 1999; Nobes, 2004; Tay and Parker, 1990). The difference between the two types of accounting harmonization is clearly surprised on a conceptual level and emphasized by Fontes et al. (2005). Therefore formal harmonization focuses on how accounting standards are developed while material harmonization analyzes the level of comparability and concordance proven by actual accounting practices in relation to the implementation process of accounting standards when considering national accounting systems.

Moving forward we can state that formal harmonization actually represents a first indispensable step in achieving material harmonization. Even though we accept the existence of alternative solutions and realities we believe that reaching the objective of financial reporting practices that are globally accepted requires an intermediate phase of harmonizing accounting regulations. Under these circumstances we consider that accounting harmonization represents a real process (Tay and Parker, 1990; van der Tas, 1988) and seems to be essential in order to improve international comparability of financial statements, therefore increasing cash flows' mobility and reducing costs in terms of financial statements' preparation especially in the case of multinational companies (Carey, 1990; Choi and Mueller, 1992). Rahman et al. (2002) consider that accounting harmonization assumes four essential aspects as follows: (1) the influences, (2) the process, (3) the result and (4) the consequences. The influences comprise those factors that have a certain impact on accounting practices' harmonization. The process assumes the assembly of steps or efforts that are developed by companies in order to reduce existent differences of accounting practices. The result refers to the level of harmony being reached at a certain moment in time. Consequences refer to subsequent effects of the harmonization process.

Beyond the above discussed elements of the accounting harmonization process we must also consider the fact that in case those aspects that are generally considered as other influences, at one moment in time, benefit of strong attributes and develop a high ability to influence the accounting harmonization process, then we can assist the manifestation of a different form of this process, known within research 
literature as spontaneous harmonization. A series of studies (Canibano and Mora, 2000; Garrido et al., 2002; Huddart and Hughes, 1999; Meek et al., 1995; Meek and Gray, 1989; Taylor-Zarzeski, 1996) develop the theoretical framework and/or empirical evidences for the spontaneous harmonization tendency that was found at the level of accounting practices of the so-called global players.

It is therefore necessary to make the distinction between the two main types of harmonization that are de facto or material harmonization and de jure or formal harmonization. References with regard to the increase of the comparability degree are based on a high degree of conformity of accounting practices and afterwards on harmonizing regulations (Canibano and Mora, 2000). They also consider that formal harmonization usually generates or favors material harmonization without this representing the only solution. More precisely, material harmonization can develop without being generated through formal harmonization as its predecessor, through the so-called spontaneous harmonization.

Tay and Parker (1990) also make a clear distinction between de jure harmonization and de facto harmonization. Through harmonization of accounting regulations (de jure harmonization) they analyze to what extent accounting standards and regulations are comparable. The latter concept (de facto harmonization) mostly analyzes to what extent accounting regulations are found within companies accounting practices (Parker, 1996). Van der Tas $(1988,1992)$ also distinguish spontaneous harmonization besides formal harmonization and material harmonization. Furthermore, spontaneous harmonization represents a subcategory or a particular form of material harmonization (Parker and Morris, 2001). The approach in accordance to which material harmonization can be reached without first going through formal harmonization is also argued by van der Tas (1988).

We can say that two main forces are involved within the international accounting harmonization process: (1) institutional efforts for international accounting harmonization through the development of common accounting rules and standards and (2) spontaneous efforts of global players in order to adopt accounting methods that should improve their communication with accounting information's users in other countries (Canibano and Mora, 2000). This two forces act simultaneously, consolidating each other, but in some cases acting independently under the umbrella of the globalization phenomenon. 
Spontaneous accounting harmonization can be considered as a deviation from or alternative to the natural/classical evolution of the accounting harmonization process. Such a deviation incurs when some deficiencies characterize the process of harmonizing regulations or when the pace of this harmonization process does not correspond to financial reporting's need for comparability as expressed through accounting practices and realities. In other words we can consider that spontaneous harmonization is a reaction of response to the need for accounting harmonization coming from accounting practice. Spontaneous accounting harmonization therefore develops due to forces of the market and not to accounting regulations (Parker and Morris, 2001) and their harmonization.

We can observe that instruments measuring the compatibility degree of accounting practices and of different sets of accounting regulation actually record a convergent time evolution towards the common point given through measurement instruments based on similarity. Moreover, a clearer dimensioning of the accounting harmonization degree is obtained when using either association coefficients (Jaccard's Coefficients, Roger-Tanimoto Coefficient, Lance-Williams Coefficient), either correlation coefficients (Pearson Coefficient, Spearman Coefficient).

Jaccard's Coefficients are mostly known in the form being used by Fontes et al. (2005), as follows:

$$
S_{i j}=\frac{a}{a+b+c},
$$

where $S_{i j}=$ the similarity degree between the two sets of analyzed accounting regulations or practices;

$a=$ the number of elements which take the 1 value for both sets of regulations or practices;

$b=$ the number of elements which take the 1 value within the $j$ set of regulations or practices and the 0 value for the i set of regulations or practices;

$c=$ the number of elements which take the 1 value within the $i$ set of regulations or practices and the 0 value for the $\mathrm{j}$ set of regulations or practices.

and 


$$
D_{i j}=\frac{b+c}{a+b+c},
$$

where $D_{i j}=$ the degree of dissimilitude or diversity between the two sets of analyzed accounting regulations or practices

The values that can be recorded by these coefficients go from 0 to 1 , where 1 represents a maximum level of harmonization when considering the similarity coefficient. Also, the sum of the two Jaccard's Coefficients, Jaccard $\mathrm{S}_{\mathrm{ij}}$ and $D_{i j}$, is obviously always equal to 1 . Jaccard's Coefficients will further be used within the next section of this chapter in order to measure formal accounting harmonization between National Accounting Regulations and the IFRS/SME.

As another model for measuring the consistencies between accounting systems could be considered Roger-Tanimoto coefficient. The computation formula is following:

$$
R \& T=\frac{d+a}{d+a+2(b+c)},
$$

where $d=$ the number of elements which take the 0 value for both sets of regulations or practices.

Alternatively for measuring of dissimilarities could be used LanceWilliams coefficient. The computation formula is following:

$$
L \& W=\frac{b+c}{2 a+b+c} .
$$

\section{Results and Their Discussion}

We will discuss now the compatibility levels between all sets of national harmonization with international referential. For the compatibility calculation were used Jaccard's coefficients (for measurement of similarities and dissimilarities), Roger-Tanimoto coefficient (for measurement of similarities) and Lance-Williams coefficient (for measurement of dissimilarities).

All sets of accounting regulations were tested within 8 particular areas: (i) intangible assets, (ii) PPE, (iii) investment properties, (iv) financial leases, (v) inventories, (vi) financial assets and liabilities, (vii) 
financial derivatives, and (viii) financial statements. Discussed issues are part of Appendix. Tab. 2 and Tab. 3 provide evidence about measurement of similarity and dissimilarity level between all accounting regulations (Czech, IFRS, IFRS for SMEs).

Tab. 2: Similarity Analysis

\begin{tabular}{|l|c|c|c|c|}
\hline \multicolumn{2}{|c|}{ System } & CZE & IFRS & SME \\
\hline \multirow{3}{*}{ CZE } & $J C$ & 1.0000 & 0.5455 & 0.5667 \\
\cline { 2 - 5 } & $R T$ & 1.0000 & 0.3750 & 0.4348 \\
\hline \multirow{4}{*}{ IFRS } & $J C$ & 0.5455 & 1.0000 & 0.8621 \\
\cline { 2 - 5 } & $R T$ & 0.3750 & 1.0000 & 0.7838 \\
\hline IFRS/SME & $J C$ & 0.5667 & 0.8621 & 1.0000 \\
\cline { 2 - 5 } & $R T$ & 0.4348 & 0.7838 & 1.0000 \\
\hline
\end{tabular}

Source : own analysis

Tab. 3: Dissimilarity Analysis

\begin{tabular}{|l|c|c|c|c|}
\hline \multicolumn{2}{|c|}{ System } & CZE & IFRS & SME \\
\hline CZE & $J C$ & 0.0000 & 0.4545 & 0.4333 \\
\cline { 2 - 5 } & $L W$ & 0.0000 & 0.2941 & 0.2766 \\
\hline \multirow{3}{*}{ IFRS } & $J C$ & 0.4545 & 0.0000 & 0.1379 \\
\cline { 2 - 5 } & $L W$ & 0.2941 & 0.0000 & 0.0741 \\
\hline \multirow{2}{*}{ FRS/SME } & $J C$ & 0.4333 & 0.1379 & 0.0000 \\
\cline { 2 - 5 } & $L W$ & 0.2766 & 0.0741 & 0.0000 \\
\hline
\end{tabular}

Source: own analysis

Results proof the close linkage between big set of IFRS with separate standard IFRS for SMEs. Czech accounting system is slightly closer to IFRS for SMEs, however there shall be pointed out the major differences as follows:

- facultative preparation of Cash Flow Statement and Statement of Changes in Equity under Czech accounting system,

- application of "form-over-substance" for financial leases treatment in Czech

- much lower level of disclosure. 


\section{Conclusion}

IFRS information can help SMEs involved in buying or selling goods or services across national borders to initiate new relationships with customers and suppliers. As the spread and acceptance of IFRS grows internationally, so does the importance of IFRS financial statements as a tool to cultivate a positive image. It is not only large foreign groups that now demand financial statements from SMEs as part of the process of supplier selection and evaluation.

Strength of SMEs (small and smaller medium enterprises in particular) consists in their higher flexibility and to a certain point also in their innovative creativity. The standard offers an opportunity for entities without public accountability to adopt a reporting framework that nay lighten their reporting burden, if permitted by local regulation. Furthermore, it could facilitate an internationally recognized common reporting language for entities that meet the definition of an SME as set out in the standard.

Having financial information that is universally understood and comparable to other companies' information can improve relationships with customers, suppliers, investors and bankers. If these business partners have more confidence in the financial information being provided using IFRS, this can be a crucial factor in securing a new supplier, obtaining finance, reducing the cost of borrowing, and arriving at an acquisition or cooperation agreement.

Adoption of IFRS for SMEs could be vital for true-and-fair view and for the higher comparability of accounting information in globalized world. The crucial necessity will be the wider spread of IFRS for SMEs knowledge. Generally, IFRS for SMEs is based on different concept than continental accounting regulation, so it'll be not only about the training of new accounting regulation, but about the training of the different accounting thinking and different approach for posting of accounting transaction. There will be also necessary to provide regular information for professional accountants about the evolution and changes in IFRS for SMEs and the long-life training.

As a possible limit for the current adoption of IFRS for SMEs could be considered the lack of motivation as the clients of professional accountants prefer rather than true-and-fair view the best solution of accounting operation from the tax point of view, due to the close connection of national accounting systems to tax regulation. 


\section{References}

[1] Abdel-Khalik, R. A. (1983): Financial Reporting by Private Companies: Analysis and Diagnosis. Norwalk, Financial Accounting Standards Board, 1983.

[2] Alexander, D. - Servalli, S. (2009): Accounting Regulatory Change: Towards a General Model. In: $32^{\text {nd }}$ Annual Congress of the EAA. Tampere, European Accounting Association, c2009.

[3] Barker, P. - Noonan, C. (1996): Small Company Compliance with Accounting Standards: The Irish Situation. Dublin, Dublin City University Business School Working Paper no. 10, 1996.

[4] Canibano, L. - Mora, A. (2000): Evaluating the Statistical Significance of De Facto Accounting Harmonization: A Study of European Global Players. European Accounting Review, 2000, vol. 9, no. 3, pp. 349-369.

[5] Carey, A. (1990): Harmonization: Europe Moves Forward. Accountancy, 1990, vol. 19, no. 3, pp. 92-93.

[6] Carsberg, B. - Page, M. - Sindall, A. - Waring, I. (1985): Small Company Financial Reporting. Englewood Cliffs, Prentice Hall, 1985.

[7] Choi, F. D. S. - Mueller, G. G. (1992): International Accounting. Upper Saddle River, Prentice Hall, 1992.

[8] Collis, J. - Dugdale, D. - Jarvis, R. (2001): Deregulation of Small Company Financial Reporting in the UK. In McLeay, S. Riccaboni, A. (eds.): Contemporary Issues in Accounting Regulation. Boston, Kluwer, 2001, pp. 167-185,

[9] Collis, J. - Jarvis, R. (2000): How Owner-Managers Use Accounts. London, Institute of Chartered Accountants in England and Wales, 2000.

[10] Collis, J. - Jarvis, R. - Skerratt, L. (2004): The Demand for the Audit in Small Companies in the UK. Accounting and Business Research, 2004, vol. 34, no. 2, pp. 87-100.

[11] Ding, Y. - Stolowy, H. - Tenenhaus, M. (2003): Shopping Around for Accounting Practices: The Financial Statement Presentation of French Groups. Abacus, 2003, vol. 39, no. 1, pp. 42-65.

[12] Eirle, B. (2005): Differential Reporting in Germany - A Historical Analysis. Accounting, Business \& Financial History, 2005, vol. 15, no. 3, pp. 279-315. 
[13] Evans, L. et al. (2005): Problems and Opportunities of an International Financial Reporting Standard for Small and Medium-sized Entities: The EAA FRSC's Comment on the IASBC's Discussion Paper. Accounting in Europe, 2005, vol. 2, no. 1, pp. 23-45.

[14] Fontes, A. - Rodrigues, L. L. - Craig, G. (2005): Measuring Convergence of National Accounting Standards with International Financial Reporting Standards. Accounting Forum, 2005, vol. 29, no. 4, pp. 415-436.

[15] Garrido, P. - Leon, A. - Zorio, A. (2002): Measurement of Formal Harmonization Progress: The IASC Experience. International Journal of Accounting, 2002, vol. 37, no. 1, pp. 1-26.

[16] Hoogendoorn, M. (2006): International Accounting Regulation and IFRS Implementation in Europe and Beyond - Experiences with First-Time Adoption in Europe. Accounting in Europe, 2006, vol. 3, no. 1, pp. 23-26.

[17] Huddart, S. - Hughes, J. S. (1999): Disclosure Requirements and Stock Exchange Listing Choice in an International Context. Journal of Accounting and Economics, 1999, vol. 26, no. 1-3, pp. 237-269.

[18] Jermakowicz, E. K. - Gornik-Tomaszewski, S. (2006): Implementing IFRS from the Perspective of EU Publicly Traded Companies. Journal of Accounting, Auditing and Taxation, 2006, vol. 15, no. 2, pp. 170-196.

[19] Larson, R. K. - Kenny, S. Y. (1999): The Harmonization of International Accounting Standards: Progress in the 1990s? Multinational Business Review, 1999, vol. 7, no. 1, pp. 1-12.

[20] Larson, R. K. - Street, D. L. (2004): Convergence with IFRS in an Expanding Europe: Progress and Obstacles Identified by Large Accounting Firms' Survey. Journal of Accounting, Auditing and Taxation, 2004, vol. 13, pp. 89-119.

[21] Maingot, M. - Zeghal, D. (2006): Financial Reporting of Small Business Entities in Canada. Journal of Small Business Management, 2006, vol. 44, no. 4, pp. 513-530.

[22] Marten, K. U. et al. (2002): Rechnungslegung nach IAS Nutzeneffekte aus Sicht von Eigenkapitalgebem. Betriebs-Berater, 2002, vol. 57, no. 39, pp. 2007-2012.

[23] Matis, D. - Strouhal, J. - Bonaci, C. G. (2009): Regulators and Regulations for Financial Instruments in the Context of Financial 
Crisis - Two Emergent Countries' Point of View. In Tsamenyi, M. - Uddin, S. (eds.): Research in Accounting in Emerging Economies. Emerald Publishing, 2009, pp. 345-378.

[24] Meek, G. K. - Roberts, C. - Gray, S. J. (1995): Factors Influencing Voluntary Annual Reports Disclosures by US, UK and Continental European Multinational Corporations. Journal of International Business Studies, 1995, vol. 26, no. 3, pp. 555-572.

[25] Meek, G. K. - Gray, S. J. (1989): Globalization of Stock Markets and Foreign Listing Requirements: Voluntary Disclosures by Continental European Companies Listed on the London Stock Exchange. Journal of International Business Studies, 1989, vol. 20, no. 2, pp. 315-336.

[26] Nobes, C. (2004): On Accounting Classification and the International Harmonization Debate. Accounting, Organizations and Society, 2004, vol. 29, no. 2, pp. 189-200.

[27] Pacter, P. (2004): Will the GAAP Widen for SMEs? Accountancy, 2004, vol. 133, no. 1325, pp. 118-122.

[28] Page, M. J. (1984): Corporate Financial Reporting and the Small Independent Company. Accounting and Business Research, 1984, vol. 12, no. 47, pp. 271-283.

[29] Parker, R. H. (1996): Harmonizing the Notes in the UK and France: A Case Study in De Jure Harmonization. European Accounting Review, 1996, vol. 5, no. 2, pp. 317-337.

[30] Parker, R. H. - Morris, R. D. (2001): The Influence of US GAAP on the Harmony of Accounting Measurement Policies of Large Companies in the UK and Australia. Abacus, 2001, vol. 37, no. 3, 2001, pp. 297-328.

[31] Pratten, C. (1998): The Uses of the Accounts of Small and MediumSized Companies and the Effects of the Audit Exemption Regime. London, Institute of Chartered Accountants in England and Wales, 1998.

[32] Rahman, A. - Perera, H. - Ganesh, S. (2002): Accounting Practice Harmony, Accounting Regulation and Firm Characteristics. Abacus, 2002, vol. 38, no. 1, pp. 46-77.

[33] Schipper, K. (2005): The Introduction of IAS in Europe: Implications for International Convergence. European Accounting Review, 2005, vol. 14, no. 1, pp. 101-126. 
[34] Soderstrom, N. S. - Sun, K. J. (2007): IFRS Adoption and Accounting Quality: A Review. European Accounting Review, 2007, vol. 16, no. 4, pp. 675-702.

[35] Strouhal, J.(2011)(ed.): Harmonization of SMEs Financial Reporting in Emerging CEE Countries. Athens, WSEAS Press, 2011.

[36] Strouhal, J. - Židlická, R. - Knapová, B. - Cardová, Z. (2011): Účetnictví 2011: Velká kniha př́kladů. Brno, Computer Press, 2011.

[37] Strouhal, J. - Deari, F. (2010): Comparative Analysis of the Reporting Bases of Czech Republic, Macedonia and Albania with IFRS. Global Review of Accounting and Finance, 2010, vol. 1, no. 1, pp. 41-59.

[38] Strouhal, J. - Müllerová, L. - Cardová, Z. - Paseková, M. (2009): National and International Financial Reporting Rules: Testing the Compatibility of Czech Reporting from the SMEs Perspective. WSEAS Transactions on Business and Economics, 2009, vol. 6, no. 12 , pp. 620-629.

[39] Sucher, P. - Jindřichovská, I. (2004): Implementing IFRS: A Case Study of the Czech Republic. Accounting in Europe, 2004, vol. 1, no. 1 , pp. 109-141.

[40] Tay, J. S. W. - Parker, R. H. (1990): Measuring International Harmonization and Standardization. Abacus, 1990, vol. 26, no. 1, pp. 71-88.

[41] Taylor-Zarzeski, M. (1996): Spontaneous Harmonization Effects of Culture and Market Forces on Accounting Disclosure Practices. Accounting Horizons, 1996, vol. 10, no. 1, pp. 18-37.

[42] Van der Tas, L. G. (1992): Evidence of EC Financial Reporting Practice Harmonization: The Case of Deferred Taxation. European Accounting Review, 1992, vol. 1, no. 1, pp. 69-104.

[43] Van der Tas, L. G. (1988): Measuring Harmonization of Financial Reporting Practice. Accounting and Business Research, 1988, vol. 18, no. 70, pp. 157-169.

[44] Tokar, M. (2005): Convergence and the Implementation of a Single Set of Global Standards: The Real-life Challenge. Accounting in Europe, 2005, vol. 2, no. 1, pp. 47-68.

[45] Vellam, I. (2004): Implementation of IFRS in Poland: Can True Convergence Be Achieved in Practice? Accounting in Europe, 2004, vol. 1, no. 1, pp. 143-167. 


\section{Appendix - Analysed Segments}

\begin{tabular}{|l|c|c|c|}
\cline { 2 - 4 } \multicolumn{1}{c|}{} & CZE & IFRS & SME \\
\hline 1 Intangibles & & & \\
\hline Initial Recognition & & & \\
\hline$\bullet \quad$ historical costs & $\mathrm{x}$ & $\mathrm{x}$ & $\mathrm{x}$ \\
\hline Revaluation & & & \\
\hline$\bullet \quad$ historical costs & & $\mathrm{x}$ & $\mathrm{x}$ \\
\hline$\bullet \quad$ fair value (up-equity, down-P/L) & & & \\
\hline 2 PPE & & & \\
\hline Initial Recognition & $\mathrm{x}$ & $\mathrm{x}$ & $\mathrm{x}$ \\
\hline$\bullet \quad$ historical costs & & & \\
\hline Revaluation & $\mathrm{x}$ & $\mathrm{x}$ & $\mathrm{x}$ \\
\hline$\bullet \quad$ historical costs & & $\mathrm{x}$ & \\
\hline$\bullet \quad$ fair value (up-equity, down-P/L) & & & \\
\hline 3 Investment Properties & & & \\
\hline Initial Recognition & $\mathrm{x}$ & $\mathrm{x}$ & $\mathrm{x}$ \\
\hline$\bullet \quad$ historical costs & & & \\
\hline Revaluation & $\mathrm{x}$ & $\mathrm{x}$ & \\
\hline$\bullet \quad$ historical costs & & $\mathrm{x}$ & $\mathrm{x}$ \\
\hline$\bullet \quad$ fair value (P/L) & & & \\
\hline 4 Financial Leases & & & \\
\hline Lessor & $\mathrm{x}$ & & \\
\hline$\bullet \quad$ recognition of fixed asset at historical costs & $\mathrm{x}$ & & \\
\hline$\bullet \quad$ depreciation of fixed asset & & & \\
\hline Lessee & & $\mathrm{x}$ & $\mathrm{x}$ \\
\hline$\bullet \quad$ depreciation of fixed asset & & & $\mathrm{x}$ \\
\hline$\bullet \quad$ recognition of fixed asset at present value & $\mathrm{x}$ & $\mathrm{x}$ \\
\hline$\bullet \quad$ off balance sheet evidence of fixed asset & $\mathrm{x}$ & $\mathrm{x}$ & $\mathrm{x}$ \\
\hline 5 Inventories & & & \\
\hline Initial Recognition & & & \\
\hline$\bullet \quad$ historical costs & & & \\
\hline Derecognition & & & \\
\hline$\bullet \quad$ FIFO & & & \\
\hline$\bullet \quad$ weighted average & & & \\
\hline
\end{tabular}




\begin{tabular}{|l|c|c|c|}
\cline { 2 - 4 } \multicolumn{1}{c|}{} & CZE & IFRS & SME \\
\hline 6 Financial assets and liabilities & & & \\
\hline Initial Recognition & & & \\
\hline$\bullet \quad$ historical costs & $\mathrm{x}$ & $\mathrm{x}$ & $\mathrm{x}$ \\
\hline$\bullet \quad$ fair value & & $\mathrm{x}$ & $\mathrm{x}$ \\
\hline Derecognition & & & \\
\hline$\bullet \quad$ historical costs & & $\mathrm{x}$ & $\mathrm{x}$ \\
\hline$\bullet \quad$ present value & $\mathrm{x}$ & $\mathrm{x}$ & $\mathrm{x}$ \\
\hline$\bullet \quad$ amortized costs & $\mathrm{x}$ & $\mathrm{x}$ & $\mathrm{x}$ \\
\hline$\bullet \quad$ fair value (P/L) & & & \\
\hline 7 Derivatives & & & \\
\hline Initial Recognition & $\mathrm{x}$ & & \\
\hline$\bullet \quad$ historical costs & & $\mathrm{x}$ & $\mathrm{x}$ \\
\hline$\bullet \quad$ fair value & & & \\
\hline Derecognition & $\mathrm{x}$ & $\mathrm{x}$ & $\mathrm{x}$ \\
\hline$\bullet \quad$ fair value (P/L) & $\mathrm{x}$ & $\mathrm{x}$ & $\mathrm{x}$ \\
\hline$\bullet \quad$ fair value (equity) & & & \\
\hline $\mathbf{8}$ Obligatory Financial Statements & $\mathrm{x}$ & $\mathrm{x}$ & $\mathrm{x}$ \\
\hline Balance Sheet (Statement of Financial Position) & $\mathrm{x}$ & $\mathrm{x}$ & $\mathrm{x}$ \\
\hline P/L Statement (Statement of Financial Performance) & & $\mathrm{x}$ & $\mathrm{x}$ \\
\hline Statement of Comprehensive Income & & $\mathrm{x}$ & $\mathrm{x}$ \\
\hline Statement of Changes in Equity & & $\mathrm{x}$ & $\mathrm{x}$ \\
\hline Cash-flow Statement & $\mathrm{x}$ & $\mathrm{x}$ & $\mathrm{x}$ \\
\hline Notes & & \\
\hline
\end{tabular}




\title{
Comparative Analysis of Czech Accounting with International Regulation from SMEs Perspective
}

Jiř́ STROUHAL - Marie PASEKOVÁ - Libuše MÜLLEROVÁ

\begin{abstract}
Use of harmonized accounting standards may reduce investor's uncertainty and can thus reduce the cost of capital. It can significantly improve the communication between business users and all their statements. Due to the globalization of business and international harmonization of financial reporting Czech Republic experiences a shift in paradigms from historical costs accounting towards fair value measurement. Paper provides an analysis between national accounting legislature and international referential. There is also provided how the ability to measure accounting harmonization can be helpful from the perspective of a globalized world. A comparative analysis between Czech accounting regulation and IFRS or IFRS for SMEs show the level of compatibility between these three sets of accounting regulation.

Key words: International harmonization; Globalization; International Financial Reporting Standards; Econometric tools; Czech Republic.
\end{abstract}

JEL classification: M41. 